\title{
Prospect of Algal Biodiesel as a Fuel in Engine
}

\author{
Sandeep Kumar Duran, Pramod Kumar, Sarbjot S Sandhu
}

\begin{abstract}
The fossil fuel consumption has been swiftly increase by the robust industrialization and increasing living standard of society. So the biodiesel fuel becomes more popular material among the research for get ride over these problems because it is green fuel, sustainable and renewable. A microalga is the fastest growing species with high oil cosntents (up to 60\%). In organic solvent extraction method, polar (methanol) and non-polar (hexane) solvents are preferred for oil extraction. GLC technique is used for esterification and seventeen forms of fatty acids are identified. A large amount of Cis-11-eicosanoic acid (41.80\%) is found in algae oil. Different catalysts i.e. $\mathrm{NaOH}, \mathrm{CaO}$ (Egg Shell), and $\mathrm{H}_{2} \mathrm{SO}_{4}$, with methanol is used for biodiesel preparation. The fuel properties are premeditated for blends i.e. B10, B20, B30, B50 and B100 as per standards. Pure biodiesel attributes like density, kinematic viscosity they are within biodiesel standards. Many researches pragmatic that these physicochemical properties of biodiesel has great influence on engine performance, so this article provides guidance for examine the behaviour of biodiesel in engine based upon their physiochemical properties.
\end{abstract}

Keywords: Microalgae, lipid, transesterification, biodiesel and fuel properties.

\section{INTRODUCTION}

The unpredictable and fluctuating prices of fossil fuel rise immense challenges for importer countries. For any country transport sector is foremost component which affect the growth and welfare of society. The transport sector utilized more than $50 \%$ of total world's oil consumption. The world's oil consumption by transportation sector was hiked by $40 \%$ in 2016 when compared to 1973 [1]. For environmental concern, engine emits more harmful pollutants like Nitrogen oxides $\left(\mathrm{NO}_{\mathrm{X}}\right)$, smoke, carbon dioxide $\left(\mathrm{CO}_{2}\right)$, and particulate matter (PM). Most dangerous pollutants are $\mathrm{NO}_{\mathrm{X}}$ and smoke, the carbon dioxide is responsible for producing greenhouse effect which leads to climate change. Fig 1 shows the contribution of the transport sector in total world's emissions. Many countries have taken ingenuity for augment the alternative energy research. Biodiesel is most promising alternative fuel for

Revised Manuscript Received on October 30, 2019.

* Correspondence Author

Sandeep Kumar Duran,* Department of Mechanical Engineering, Dr. B. R. Ambedkar National Institute of Technology, Jalandhar, Punjab, 144011 India.

Pramod Kumar, Department of Mechanical Engineering, Dr. B. R. Ambedkar National Institute of Technology, Jalandhar, Punjab, 144011 India.

Sarbjot S Sandhu, Department of Mechanical Engineering, Dr. B. R. Ambedkar National Institute of Technology, Jalandhar, Punjab, 144011 India.

(C) The Authors. Published by Blue Eyes Intelligence Engineering and Sciences Publication (BEIESP). This is an open access article under the CC BY-NC-ND license (http://creativecommons.org/licenses/by-nc-nd/4.0/) diesel engine [2].

India is highly populated country in the world, nearly 5th of the world's population. Coal (408 Mtoe) and oil (196 Mtoe) are used for satisfying the primary energy requirement of India. India is 3rd largest consumer of petroleum with five time higher diesel fuel consumption as compared to gasoline [2].

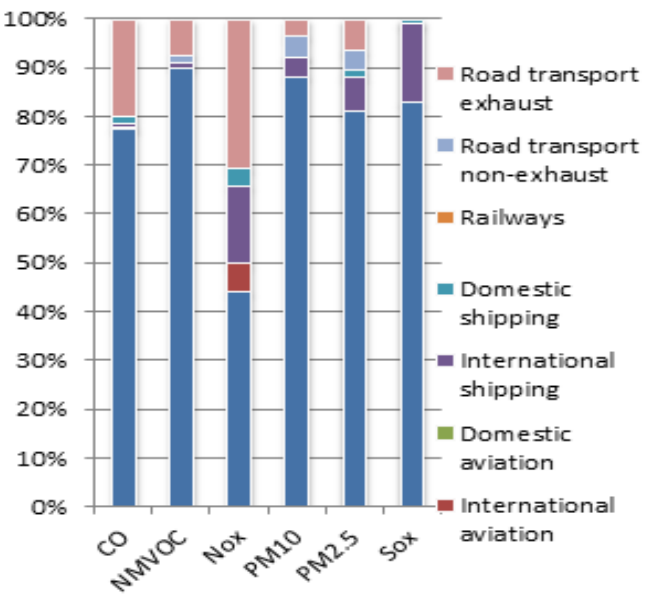

Fig. 1. Contribution of transport sector in total world's emissions

According to International Organization of Motor Vehicle Manufacturers in 2015 around 28,860 thousand motor vehicle was registered as it was 17950 thousand unit in 2005 as shown in Fig 2. India is 3rd most polluting country after China and United States, fourteen out of the world's 15 highly contaminated cities are in India (Source: UNHCR, World Bank). India will face grievous energy deficiency in coming couple of decade due to mass energy scarcity and boost in energy prices. Each year the oil consumption has increased, 8.1\% increase in 2015 as compared to 2014. India produces only $0.5 \%$ biofuel of the total world share in 2014 but it hiked to $13.1 \%$ in 2015. MNRE (Ministry of New and Renewable Energy) of India propose $20 \%$ blending of biofuel to fossil fuel by 2017, which is a step towards promotion of renewable energy source but still government need to take some serious action for promotion of renewable energy sources. Selection of feedstock for biodiesel production generally depends upon the availability and country economic aspects. USA and Brazil, using soybean oil but Canada using canola oil for biodiesel production. UK, Germany, Italy and Finland are utilizing rapeseed oil as feedstock. Indonesia and Malaysia depend on palm and coconut oil due surplus amount production of these oils. The biodiesel is also produce from jatropha oil, karanja oil, neem oil, Mahua oil, sun flower oil, rice bran oil and mustard oil. There are wide ranges of feedstocks for biodiesel production. Based upon type of feedstock the biodiesel are classified as, first generation, second and third generation.

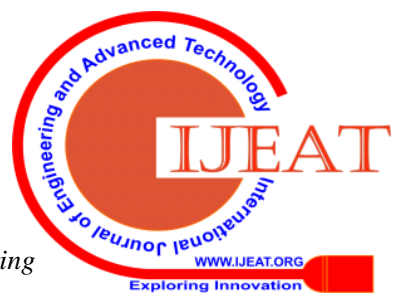


First generation biodiesel had direct entrenched upon the food chain because they are produced from edible vegetable oil. Biodiesel derived from mustard oil, rice bran oil, wheat oil, coconut oil, palm oil etc. are categorized as first generation biodiesel.

\section{Motor Vechile registered}

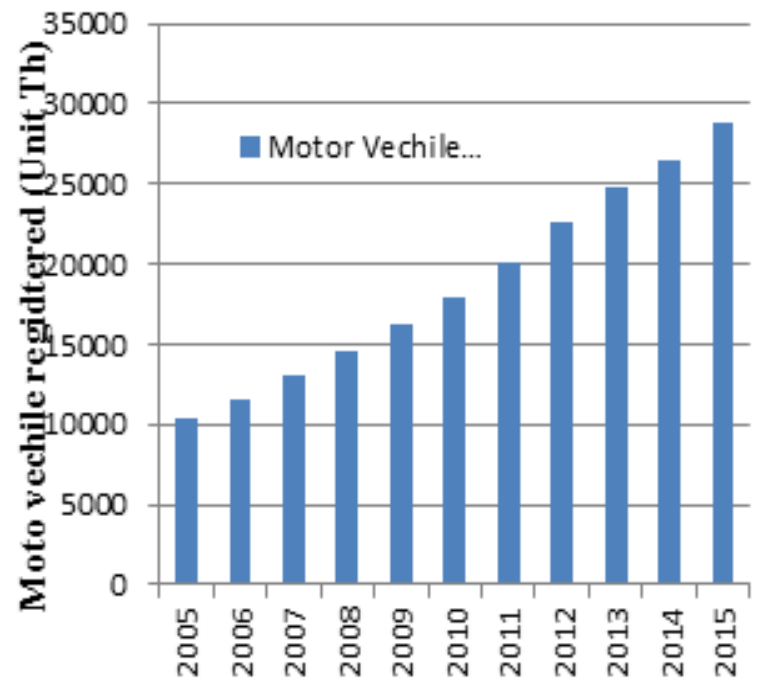

Year

Fig. 2.Motor vehicle registered in India

Second generation biodiesel are produced from non-edible vegetable oil, so there is no impact on food chain. Feedstocks for second generation biodiesel are jatropha, karanja, neem, rubber seed, Mahua, waste and lignocelluloses etc. They can easily grow on non-agricultural land which is additional advantage as compared to first generation feedstock. Second generation biofuels are facing scarcity of efficient technologies for conversion. The third generation biofuels are produced from algae, which will get rid of the downsides of first and second generation. Microalgae reported as the best alternative of biomass feedstock to produce biodiesel, owing to its high biomass productivity (produce double biomass within two days) and oil contents. Some of its species like schizochytrium have $77 \%$ oil contents [3]-[4]. Different methods and technologies are practiced for algal biodiesel production [5], with processes of harvesting of algal biomass, preparation of dry algae powder, oil extraction with solvents or mechanical pressing and conversion of oil to biodiesel.

This article is directed to identify a more reliable method for biodiesel production from algal material, using: two step transesterification i.e. two unlike extraction method for oil extraction, conversion of oil to biodiesel with menthol in presence of catalyst and single step transesterification i.e. conversion of algal biomass direct using in situ transesterification. In the interest for successful market acceptance and commercialization of biodiesel, the properties and fuel quality should be as per standards. Commonly ASTM D6751 and EN14214 are used so we compared the fuel properties of algal biodiesel with their different blends with standards and do the analysis. There is great influence of physicochemical properties of biodiesel on engine performance, so this article provides guidance for examine the behaviour of biodiesel in engine.

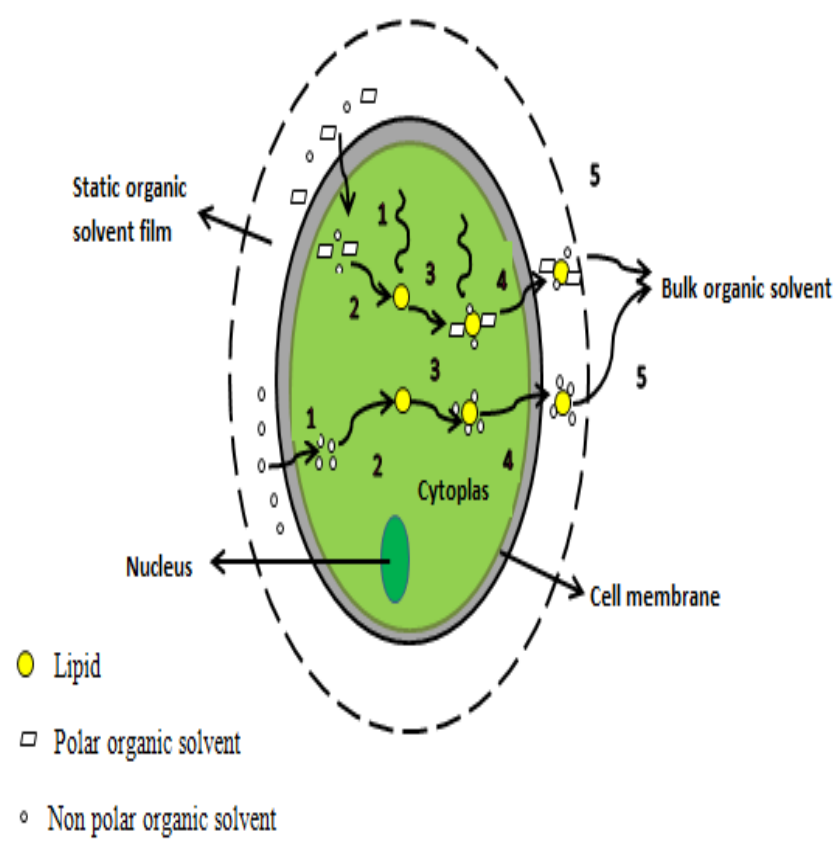

Fig. 3.The mechanism of organic solvent extraction

\section{MATERIAL AND METHODS}

\section{A. Harvesting}

The selection of effective harvesting method play important role because around 2-60\% of the total biodiesel production cost is involved in harvesting process. Algal biomass was harvested from media with centrifugation. Algae based water treatment is not used due to lack of efficient and cost effective technology. Harvesting technique are like sedimentation, centrifugation and flotation are used but no single strategy is best for harvesting, so combination of two technique like flocculation and sedimentation are used for best result [5]. 


\section{B. Oil extraction}

The Different chemical solvent methods were used to extract algal oil from the dried biomass. The two extraction methods are; organic solvent extraction and supercritical fluid extraction (SCFE). Organic solvent extraction method is preferred over SCFE method for economical motive. Organic solvent extraction works on "like dissolving like" concept. Polar solvents (isopropanol/methanol) and non-polar solvents (hexane/chloroform) was used together for better extraction results. Soxhlet apparatus as shown in Fig. 3 is used which obligates three compartments, i.e. condenser: for condensing evaporated solvent, heating flask: for storage of solvent and extractor: for holding algal biomass as shown in Fig 4. Evaporated solvent enter into extractor via condenser and contact directly with biomass to perform extraction. This circulation process is repeated for 8 hours (10 refluxes /hours) and after that filtration is done [5]-[6].

\section{Conversion from oil to biodiesel}

There are two conversion techniques i.e. thermochemical and biochemical. To attain biodiesel biochemical technology is practiced with two different techniques: two step transesterification and In-situ transesterification [5].

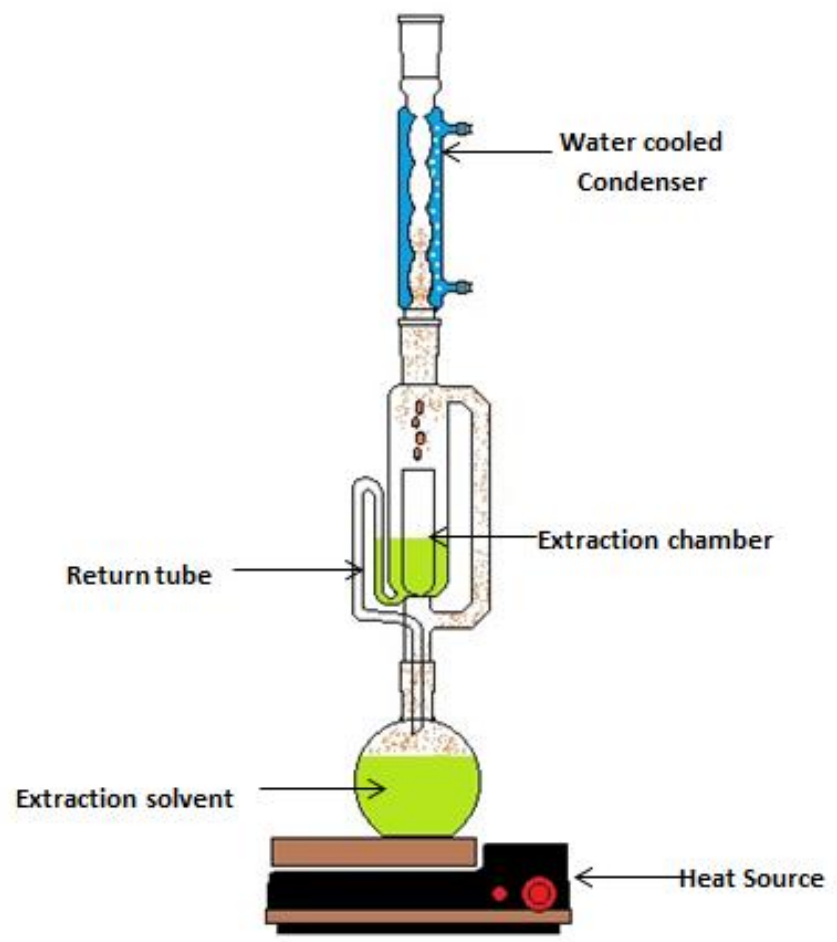

Fig. 4.Soxlet appratus

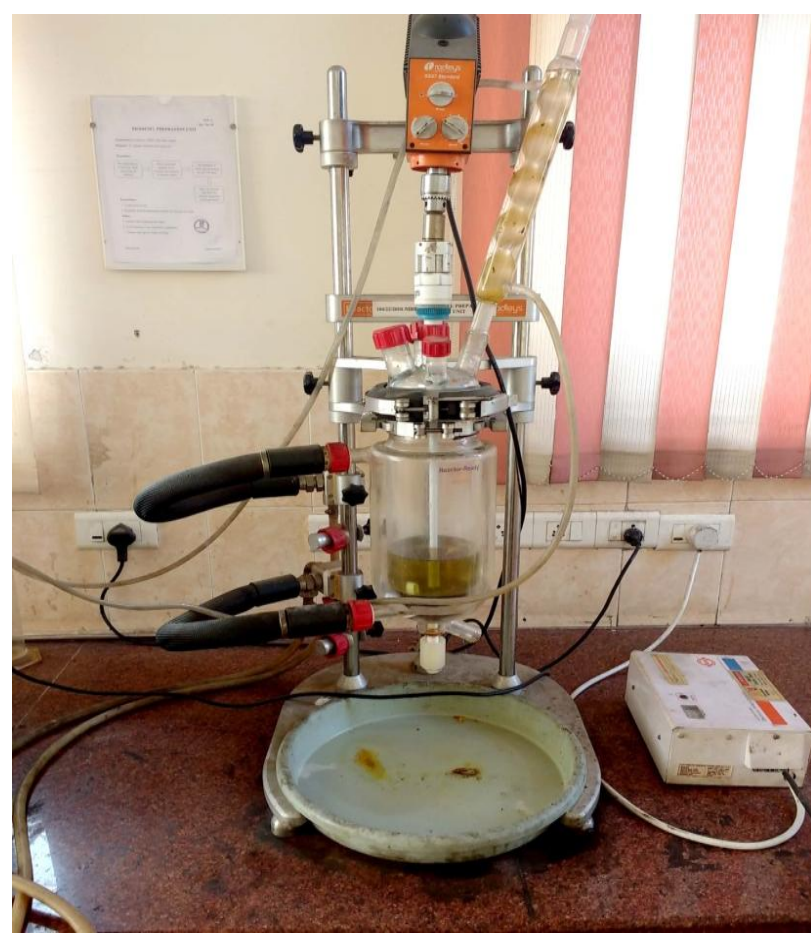

Fig. 5.Redlay recator for transesterification

\section{1) Two step (conventional) transesterification}

This conventional method is embraced with duo steps, extraction of oil from algae cell and conversion of algal oil into biodiesel the setup is shown in Fig. 5. Molar ratio 1:6 (Oil to methanol ratio) with $1 \%$ of catalyst w/w $(\mathrm{NaOH}$ and $\mathrm{CaO}$ ) is used; this reaction is carried out at $60^{\circ} \mathrm{C}$ [6]. Glycerin is assorted by gravitational method after completion of reaction.

\section{2) In-situ transesterification}

This conversion method replaced the two step conversion method. In this method, acid catalyst (sulfuric acid) 20\% w, methanol and algal biomass (powdered form) is used, reaction is carried out for 4 hour at $60^{\circ} \mathrm{C}$ temperature [5-6]. The methanol extracts the oil from the algal biomass and then sulfuric acid will convert that extracted oil into biodiesel and glycerin. Filtration is used to remove cell-debris. Lastly, Purification is done, which includes two steps, first: distillation, to remove methanol and second: gravitational method, for removal of glycerin [6].

\section{RESULT AND DISCUSSION}

\section{A. Fatty acid compositional profile}

The fatty acid composition of Chlorella sp. was evaluated at Punjab biotechnology incubator, Chandigarh. Table I showed that percentage of saturated FAMEs (13.09\%) is remarkable compared to unsaturated FAMEs (86.121\%). Large amount of Cis-11-Eicosanoic Acid (Mono Unsaturated Fatty acid) is found in algal oil. The fatty acid profile of algae strains are influenced by growth conditions i.e. temperatures, light intensities and nutrients levels. So for different algal based oil, their fatty acid profile will be different [7].

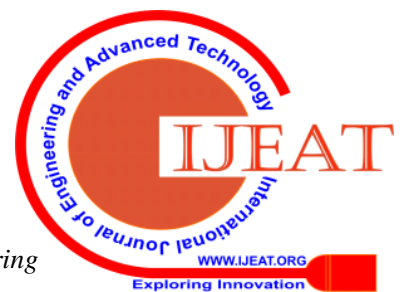


Table- I: Fatty acid profile of algae oil

\begin{tabular}{|l|l|l|l|}
\hline $\begin{array}{l}\text { Sr. } \\
\text { No }\end{array}$ & Fatty Acid & & $\%$ \\
\hline 1. & Myristic Acid (Saturated Fatty acid) & C 14 & 0.07 \\
\hline 2. & Palmitic Acid (Saturated Fatty acid) & C 16 & 7.89 \\
\hline 3. & $\begin{array}{l}\text { Palmetoleic Acid ( Mono unsaturated Fatty } \\
\text { acid) }\end{array}$ & C 16:1 & 0.071 \\
\hline 4. & Stearic Acid (Saturated Fatty acid) & C 18 & 5.13 \\
\hline 5. & Oleic Acid (Mono unsaturated Fatty acid) & C 18:1 & 23.13 \\
\hline 6. & Linoleic Acid (Poly Unsaturated Fatty acid) & C 18:2 & 20.86 \\
\hline 7. & $\begin{array}{l}\text { Linolenic Acid (Poly Unsaturated Fatty } \\
\text { acid) }\end{array}$ & C 18:3 & 0.14 \\
\hline 8. & $\begin{array}{l}\text { Cis-11-Eicosanoic Acid (Mono } \\
\text { Unsaturated Fatty acid) }\end{array}$ & C 20:1 & 41.80 \\
\hline 9. & $\begin{array}{l}\text { Erucic acid (monounsaturated omega-9 } \\
\text { fatty acid) }\end{array}$ & C 22:1 & 0.12 \\
\hline
\end{tabular}

\section{1) Effect of fatty acid profile on fuel properties}

Saturated fats can make brilliant biodiesel, but one major problem of biodiesel is that it has high melting point due to this it often solidifies at room temperature, so manual heaters is used to get rid over it. On the up side, it has a better oxidative stability and fewer $\mathrm{NO}_{\mathrm{X}}$ emissions than one from unsaturated fats. The ideal mixture of fatty acids has been suggested to be C16:1, C18:1 and C14:0 in the ratio 5:4:1.

High values unsaturated fat outcomes in lower the gel point, therefore unsaturated fats are tremendous for cold weather biodiesel production and uses. But downside is, more prone to oxidation and rancidification than their saturated counterparts [8].

\section{B. Effects of catalyst on biodiesel production}

There is high influence of catalysts and their concentration with oil on the yield of biodiesel. $1 \%(w / w) \mathrm{NaOH}$

shows $92 \%$ yield at $60^{\circ} \mathrm{C}$. $\mathrm{CaO}$ shows very low biodiesel yield (30\%), which indicates that pure $\mathrm{CaO}$ is not active. Some researchers suggest heterogeneous catalyst i.e. $\mathrm{CaO}$ along with $\mathrm{Al}_{2} \mathrm{O}_{3}$ which results better activity (97.5\% yield) with methanol /lipid molar ratio 30 at $50^{\circ} \mathrm{C}$ and 4 hours reaction time [9].

\section{Comparison between conventional transesterification and In-situ transesterification}

The $70 \%$ cost of biodiesel production includes oil extraction, purification and transesterification which can be economized by using in-situ conversion process (direct Methanolysis process). The comparison between them is shown in Table II.

Table II: Comparison between conversion technologies

\begin{tabular}{|c|c|c|c|c|c|c|c|}
\hline & $\begin{array}{c}\text { Raw } \\
\text { material }\end{array}$ & $\begin{array}{c}\text { Solvent } \\
\text { extraction }\end{array}$ & Transesterification & Purification & $\begin{array}{l}\text { Conversion } \\
\text { technology }\end{array}$ & $\begin{array}{c}\text { Installation } \\
\text { and operating } \\
\text { cost }\end{array}$ & $\begin{array}{c}\text { Production } \\
\text { rate }\end{array}$ \\
\hline Conventional & $\begin{array}{c}\text { Algal } \\
\text { biomass }\end{array}$ & oil & $\begin{array}{c}\text { Biodiesel } \\
+ \text { Glycerin }\end{array}$ & Pure biodiesel & $*$ & $* *$ & * \\
\hline In-situ & $\begin{array}{c}\text { Algal } \\
\text { biomass }\end{array}$ & & $\begin{array}{l}\text { Biodiesel } \\
+ \text { Glycerin }\end{array}$ & Pure biodiesel & $* *$ & $* * *$ & $* *$ \\
\hline
\end{tabular}

*Average, ${ }^{* *}$ Good, and $* * *$ Excellence

\section{Properties of algal biodiesel $\mathrm{v} / \mathrm{s}$ diesel}

The properties and fuel quality should be as per standards for the interest of successful market acceptance and commercialization of produced biodiesel. In Table III different fuel properties of biodiesel and its blend are compared with diesel.

Table- III: Comparison of properties between diesel, biodiesel and its blends

\begin{tabular}{|c|c|c|c|c|c|c|c|}
\hline $\begin{array}{l}\text { Propertie } \\
\text { s }\end{array}$ & $\begin{array}{l}\text { Dies } \\
\text { el }\end{array}$ & $\begin{array}{l}\text { AB1 } \\
00\end{array}$ & $\begin{array}{l}\text { AB5 } \\
0\end{array}$ & $\begin{array}{l}\text { AB3 } \\
0\end{array}$ & $\begin{array}{l}\text { AB2 } \\
0\end{array}$ & $\begin{array}{l}\text { AB1 } \\
0\end{array}$ & $\begin{array}{l}\text { Metho } \\
\text { ds }\end{array}$ \\
\hline $\begin{array}{l}\text { Density at } \\
25^{\circ} \mathrm{C} \\
(\mathrm{g} / \mathrm{cc})\end{array}$ & $\begin{array}{l}0.83 \\
3\end{array}$ & 0.88 & 0.85 & 0.84 & $\begin{array}{l}0.83 \\
8\end{array}$ & $\begin{array}{l}0.83 \\
5\end{array}$ & $\begin{array}{l}\text { ASTM } \\
\text { D7042 }\end{array}$ \\
\hline $\begin{array}{l}\text { K.Viscosi } \\
\text { ty at } 40^{\circ} \mathrm{C} \\
\text { (cSt) }\end{array}$ & 2.37 & 4.30 & 3.31 & 2.92 & 2.76 & 2.52 & $\begin{array}{l}\text { ASTM } \\
\text { D445- } \\
12\end{array}$ \\
\hline $\begin{array}{l}\text { Cetane } \\
\text { number } \\
(\mathrm{CN})\end{array}$ & 51 & 52 & 51.5 & 51.3 & 51.2 & 51.1 & \\
\hline $\begin{array}{l}\text { Cloud } \\
\text { point }\left({ }^{\circ} \mathrm{C}\right)\end{array}$ & $\begin{array}{l}-15 \\
{ }^{\circ} \mathrm{C}\end{array}$ & $\begin{array}{l}-13 \\
{ }^{\circ} \mathrm{C}\end{array}$ & $\begin{array}{l}-14 \\
{ }^{\circ} \mathrm{C} \\
\end{array}$ & $\begin{array}{l}-14 . \\
4{ }^{\circ} \mathrm{C}\end{array}$ & $\begin{array}{l}-14 . \\
6{ }^{\circ} \mathrm{C}\end{array}$ & $\begin{array}{l}-14 . \\
8{ }^{\circ} \mathrm{C}\end{array}$ & \\
\hline $\begin{array}{l}\text { Flash } \\
\text { Point }\left({ }^{\circ} \mathrm{C}\right)\end{array}$ & 58.5 & $\begin{array}{l}> \\
160\end{array}$ & 77 & 73 & 69 & 65 & $\begin{array}{l}\text { ASTM } \\
\text { D 92 }\end{array}$ \\
\hline $\begin{array}{l}\text { Carbon } \\
\text { Residue } \\
(\%)\end{array}$ & 0.13 & 0.16 & 0.08 & 0.07 & 0.07 & 0.06 & $\begin{array}{l}\text { ASTM } \\
\text { D } 524\end{array}$ \\
\hline $\begin{array}{l}\text { Sulfur } \\
\text { contents } \\
\text { (mg/kg) }\end{array}$ & 10 & 8.1 & 9.1 & 9.5 & 9.65 & 9.82 & $\begin{array}{l}\text { ASTM } \\
\text { D } 1266\end{array}$ \\
\hline Oxidation & - & 1.6 & 00.6 & 00.2 & 00.0 & 00.0 & ASTM \\
\hline
\end{tabular}

\begin{tabular}{|l|l|l|l|l|l|l|l|}
\hline $\begin{array}{l}\text { Stability } \\
\text { (Ambient } \\
\text { Temp.) } \\
\begin{array}{l}\text { Sludge(\% } \\
\text { )/Neutrali } \\
\text { zation } \\
\text { value } \\
\text { (mg) }\end{array}\end{array}$ & & & & & & & \\
\hline $\begin{array}{l}\text { Calorific } \\
\text { Value } \\
\text { (MJ/kg) }\end{array}$ & 44.8 & 22.8 & 33.2 & 35.6 & 37.2 & 38.1 & $\begin{array}{l}\text { ASTM } \\
\text { D 240 }\end{array}$ \\
\hline
\end{tabular}

\section{E. Effect of fuel properties on engine performance}

\section{1) Fuel consumption}

Fuel quantity injected in the engine is volumetrically controlled. So with higher density of fuel an increase in the fuel mass injected. The high viscosity and density of the fuel causes an increased pressure in the fuel delivery system due to the decrease in the delivery losses [11]. Higher density of biodiesel influences the engine power development, higher biodiesel concentration increase the fuel consumption due to higher viscosity indexes. This higher viscosity results improper mixing of oxygen and fuel droplets which leads to poor atomization [12]. High kinematic viscosity conducts low atomization result in incomplete combustion. Viscosity and density are most imperative properties because influence the fuel consumption, spraying, mixing and combustion processes. 
Thus, as the viscosity and density of the fuel are higher leads to increase the fuel quantity injected in the cylinder [11]-[12].

\section{2) Brake thermal efficiency}

The reduction in brake thermal efficiency (BTE) was ascribed to low atomization of fuel due to higher viscosity of biodiesel. The higher density of biodiesel acquits non uniform fuel spray in combustion chamber which leads to uneven distribution of fuel and result in incomplete combustion and reduced BTE [13]. For B20 and B30 increased trend of BTE observed which attributed to high oxygen contents of biodiesel which reduce heat low by enhances combustion [14]. At higher loads decrease drift of BTE was detected for biodiesel as compared to fossil fuel. This behaviour was ascribed to earlier start of combustion (SOC) at lower load and at higher loading condition the combustion duration will be shorter [13]-[15]. Gnanasekaran Sakthivel reported decrease in BTE and reason described of this behaviour was shorter ignition delay. Another side few research reported increase trend of BTE for biodiesel which have higher heating value [16]-[17].

\section{3) Brake specific fuel consumption (BSFC)}

Lower calorific value of biodiesel attributed to higher fuel consumption for constant power generation. Higher viscosity of biodiesel fuel results in poor mixing and improper combustion. Lower heat contents of biodiesel lead to more fuel injected into combustion chamber which increases the BSFC [18]. Higher oxygen contents fuel leads to higher BSFC due to lower heat contents of oxygenated fuel. In performance test research founded that pure diesel with $0 \%$ oxygen contents has less BSFC as compared to oxygenates fuel. [19]. High density fuel causes rich mixture locally due to non-homogeneous mixture inside combustion chamber which attributes to increase BSFC [18]. Another side very few researchers reported that BSFC decreased with biodiesel blends [20]-[21].

\section{F. Effect of fuel properties on engine emissions}

\section{1) Hydrocarbon emissions}

The incomplete combustion of fuel is the major reason for hydrocarbon (HC) emission. The HC emission is influenced by engine operating condition, fuel structure and combustion chamber design [22]. Reducing trend of HC for biodiesel was attributed to lower-self ignition temperature, higher cetane number and high oxygen contents [23]. Authors has reported that the lessened combustion duration at high speed attribute to high HC emission. Ester fuels offer higher combustion duration as compared to fossil fuel which provide more time for oxidization of fuel particles result in lower $\mathrm{HC}$ emissions [22]. In the augmentation of higher $\mathrm{HC}$ emission author reported that at lower load: poor fuel distribution, low temperature and excess air was the responsible [22]. Behçet Rasim et al. stated that HC emissions are depends upon fuel injection system and geometry of combustion chamber not on engine speed and loading [11]. Another side very few author reported that by using biodiesel as engine fuel $\mathrm{HC}$ emissions increased [24]-[25].

\section{2) Nitrogen oxides emissions}

There is no direct effect of $\mathrm{NO}_{\mathrm{X}}$ on environment, but which it react with ozone layer it converted in $\mathrm{NO}_{2}$ which have serious effect on bold hemoglobin thus stripping body tissue of oxygen which producing oxygen famishment [26]. The creations of Nitrogen oxides $\left(\mathrm{NO}_{\mathrm{X}}\right)$ in engine due to increase of temperature in combustion chamber. The high temperature during combustion reaction results in higher nitrogen oxides generation. It is highly toxic pollutants which emits from engines on account of higher oxygen contents, higher flame temperature and reaction time [20]. The formations of $\mathrm{NO}_{\mathrm{X}}$ are highly depending upon volumetric efficiency which is technically oxygen availability, combustion temperature and combustion duration. At high engine speed the gas flow motion and volumetric efficiency has been increased. The air fuel mixing improves and ignition delay reduced, result in time for $\mathrm{NO}_{\mathrm{X}}$ formation reaction will not be sufficient [21] The lower cetane number of fuel and ignition delay contributes to reduction in $\mathrm{NO}_{\mathrm{X}}$ by forcing the hot gases to stay for less time inside the combustion chamber. The higher NOx emission for biodiesel was contributed to high oxygen content which completes the combustion phase lead to higher temperature of cylinder [23]. The latent heat of vaporization of fuel, iodine number, oxygen contents, viscosity, density and cetane number was attributed to variations of $\mathrm{NO}_{\mathrm{X}}$ emission [27-29]. The higher oxygen content, iodine number, density, viscosity, air fuel ratio and lower cetane number of fuel contributed to increased trend of $\mathrm{NO}_{\mathrm{X}}$. Author claimed that combustion temperature, length of time spent at high temperature, oxidant concentration are major variable for formation of $\mathrm{NO}_{\mathrm{X}}$ emission and reduction in these variable leads to lower $\mathrm{NO}_{\mathrm{X}}$ formation. Higher humidity of air and high surface tension of fuel attribute to lower $\mathrm{NO}_{\mathrm{X}}$ emission. Very few researcher claimed reduction in $\mathrm{NO}_{\mathrm{X}}$ by using biodiesel as fuel [23-27].

\section{3) Carbon dioxide emissions}

Carbon dioxide $\left(\mathrm{CO}_{2}\right)$ is greenhouse gas and formation of $\mathrm{CO}_{2}$ indicates complete and efficient combustion process. So, $\mathrm{CO}_{2}$ is rarely had been reported as a harmful emission by any researcher. At high speed the volumetric efficiency of engine decreased which lead to insufficient oxygen for combustion and result in lower $\mathrm{CO}_{2}$ emission but inherent oxygen contents of biodiesel compensate that reduction of oxygen [20]. The increment trend of $\mathrm{CO}_{2}$ emission was attributed to higher oxygen and carbon contents in biodiesel fuel [21, 28]. Very few researchers sated that $\mathrm{CO}_{2}$ emission was decreased by using biodiesel as fuel [22-23].

\section{CONCLUSION}

The biodiesel is biodegradable and environmental friendly alternative fuel which can directly use in diesel engine without any major modification in engine. The third generation biofuel attained more attention due to advantage over first and second generation biodiesel. In this review the impact of fuel properties has been discussed in detail with deep analysis. The physiochemical properties depend upon the feedstock for biodiesel production. The deviation of properties affects the performance and emission characteristics of engine. The biodiesel and its blends in difference concentration with fossil fuel reduced emission like HC and increase trend were found for $\mathrm{CO}_{2}$ and NOx emission.Algal biomass owes highest yield and oil contents in contrast to other energy crops. In situ transesterification is having great potency over single step transesterification, featuring low production cost and high production rate. 
Properties of biodiesel are analogous to fossil fuel, shows its suitability as alternative fuel. The Sulfur contents in pure biodiesel is $8.1 \mathrm{mg} / \mathrm{kg}$, is less than the diesel fuel which leads to less HC emissions, so appropriate for current environmental scenario. Overall conclusion from this study reflects better market acceptance and commercialization of third generation biodiesel.

\section{REFERENCES}

1. Key world energy statistics, International Energy Agency; 2016.

2. P. Singh, S. K. Duran, and I. Singh, "Performance and Emission Parameters of Single Cylinder VCR Engine Fuelled with Argemone Biodiesel and Blend with Diesel Fuel," Conf. Proc. Second Int. Conf Recent Adv. Bioenergy Res. Springer Proc. Energy, 2018, pp. 29-52.

3. K. Muralidharan and D. Vasudevan, "Performance, emission and combustion characteristics of a variable compression ratio engine using methyl esters of waste cooking oil and diesel blends," Appl. Energy, vol. 88, no. 11, 2011, pp. 3959-3968.

4. S. H. Al-lwayzy and T. Yusaf, "Diesel engine performance and exhaust gas emissions using Microalgae Chlorella protothecoides biodiesel," Renew. Energy, vol. 101, 2017, pp. 690-701.

5. S. K. Duran, P. Kumar, and S. S. Sandhu, "A review on microalgae strains, cultivation, harvesting, biodiesel conversion and engine implementation," Biofuels, 2018, pp. 1-12.

6. B. Bharathiraja, R. Ranjith Kumar, R. PraveenKumar, M. Chakravarthy, D. Yogendran, and J. Jayamuthunagai, "Biodiesel production from different algal oil using immobilized pure lipase and tailor made rPichia pastoris with Cal A and Cal B genes," Bioresour. Technol., vol. 213, 2016, pp. 69-78.

7. A. Suresh, R. Praveenkumar, R. Thangaraj, F. L. Oscar, E. Baldev, D. Dhanasekaran, and N. Thajuddin, "Microalgal fatty acid methyl ester a new source of bioactive compounds with antimicrobial activity," Asian Pacific J. Trop. Dis., vol. 4, 2014, pp. 979-984.

8. E. S. Umdu, M. Tuncer, and E. Seker, "Bioresource Technology Transesterification of Nannochloropsis oculata microalga 's lipid to biodiesel on $\mathrm{Al} 2 \mathrm{O} 3$ supported $\mathrm{CaO}$ and $\mathrm{MgO}$ catalysts," Bioresour. Technol., vol. 100, no. 11, 2009, pp. 2828-2831.

9. S. Lee, D. Tanaka, J. Kusaka, and Y. Daisho, "Effects of diesel fuel characteristics on spray and combustion in a diesel engine," JSAE Rev., vol. 23, no. 4, 2002, pp. 407-414.

10. T. A. N. Pi-qiang, Z. Jian-yong, H. U. Zhi-yuan, L. O. U. Di-ming, and D. U. Ai-min, "Effects of fuel properties on exhaust emissions from diesel engines," J. Fuel Chem. Technol., vol. 41, no. 3, 2013, pp. 347-355.

11. R. Behçet, "Performance and emission study of waste anchovy fish biodiesel in a diesel engine," Fuel Process. Technol., vol. 92, no. 6, 2011, pp. 1187-1194.

12. M. Lapuerta, O. Armas, and J. Rodríguez-Fernández, "Effect of biodiesel fuels on diesel engine emissions," Prog. Energy Combust. Sci., vol. 34, no. 2, 2008, pp. 198-223.

13. S. H. Al-lwayzy and T. Yusaf, "Diesel engine performance and exhaust gas emissions using Microalgae Chlorella protothecoides biodiesel," Renew. Energy, vol. 101, 2017, pp. 690-701.

14. J. D. Mejía, N. Salgado, and C. E. Orrego, "Effect of blends of Diesel and Palm-Castor biodiesels on viscosity, cloud point and flash point," Ind. Crops Prod., vol. 43, no. 1, 2013, pp. 791-797.

15. A. Atmanli, "Effects of a cetane improver on fuel properties and engine characteristics of a diesel engine fueled with the blends of diesel, hazelnut oil and higher carbon alcohol," Fuel, vol. 172, 2016, pp. 209-217.

16. K. Muralidharan and D. Vasudevan, "Performance, emission and combustion characteristics of a variable compression ratio engine using methyl esters of waste cooking oil and diesel blends," Appl. Energy, vol. 88, no. 11, 2011, pp. 3959-3968.

17. H. An, W. M. Yang, A. Maghbouli, J. Li, S. K. Chou, and K. J. Chua, "Performance, combustion and emission characteristics of biodiesel derived from waste cooking oils," Appl. Energy, vol. 112, 2013, pp. 493-499.

18. V. Perumal and M. Ilangkumaran, "Water emulsified hybrid pongamia biodiesel as a modified fuel for the experimental analysis of performance, combustion and emission characteristics of a direct injection diesel engine," Renew. Energy, vol. 121, 2018, pp. 623-631.
19. A. Zare et al., "The effect of triacetin as a fuel additive to waste cooking biodiesel on engine performance and exhaust emissions," Fuel, vol. 182, no. 2, 2016, pp. 640-649.

20. M. A. Ghadikolaei, C. S. Cheung, and K.-F. Yung, "Study of combustion, performance and emissions of diesel engine fueled with diesel/biodiesel/alcohol blends having the same oxygen concentration," Energy, vol. 157, 2018, pp. 258-269.

21. Ö. Can, "Combustion characteristics, performance and exhaust emissions of a diesel engine fueled with a waste cooking oil biodiesel mixture," Energy Convers. Manag., vol. 87, 2014, pp. 676-686.

22. H. Sanli, M. Canakci, E. Alptekin, A. Turkcan, and A. N. Ozsezen, "Effects of waste frying oil based methyl and ethyl ester biodiesel fuels on the performance, combustion and emission characteristics of a di diesel engine," Fuel, vol. 159, no. 2015, 2015, pp. 179-187.

23. P. Pradhan, S. Chakraborty, and R. Chakraborty, "Optimization of infrared radiated fast and energy-efficient biodiesel production from waste mustard oil catalyzed by Amberlyst 15: Engine performance and emission quality assessments," Fuel, vol. 173, 2016, pp. 60-68.

24. G. Chiatti, O. Chiavola, and F. Palmieri, "Impact of waste cooking oil in biodiesel blends on particle size distributions from a city-car engine," J. Energy Inst., vol. 91, no. 2, 2018, pp. 262-269.

25. A. Atmanli, "Comparative analyses of diesel-waste oil biodiesel and propanol, n-butanol or 1-pentanol blends in a diesel engine," Fuel, vol. 176, 2016, pp. 209-215.

26. O. Özener, L. Yüksek, A. T. Ergenç, and M. Özkan, "Effects of soybean biodiesel on a DI diesel engine performance, emission and combustion characteristics," Fuel, vol. 115, 2014, pp. 875-883.

27. A. A. Abdel-Rahman, "On the emissions from internal combustion engines: A review,” Intern. J. energy Res., vol. 22, 1998, pp. 483-513.

28. E. Buyukkaya, S. Benli, S. Karaaslan, and M. Guru, "Effects of trout-oil methyl ester on a diesel engine performance and emission characteristics," ENERGY Convers. Manag., vol. 69, 2013, pp. 41-48.

29. I. Kalargaris, G. Tian, and S. Gu, "Combustion , performance and emission analysis of a DI diesel engine using plastic pyrolysis oil," Fuel Process. Technol., vol. 157, 2017, pp. 108-115.

\section{AUTHORS PROFILE}

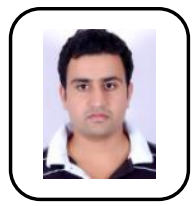
First Author
Designation
Department
Qualification
: Sandeep Kumar Duran
: PhD Research Scholar
Mechanical Engineering
M.Tech Mechanical (Dr B R
Ambedkar NIT Jalandhar), B Tech Mechanical (MDU Rohtak),

Research Interests: Alternative Fuels for Combustion Engines, IC engine Emission Control, Biodiesel Development, Algae Biofuel.

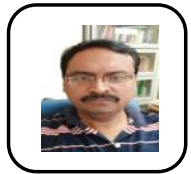

Second Author : Dr Pramod Kumar Designation : Associate Professor Department : Mechanical Engineering Qualification : PhD Mechanical (Dr B R Ambedkar NIT Jalandhar), $M$ Tech Mechanical (CIDM) (NIT Jamshedpur), B Tech Mechanical (NIT Jamshedpur),

Research Interests: Renewable Energy, composite Materials

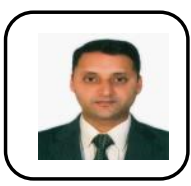

Third Author : Dr Sarbjot Singh Sandhu

Designation : Assistant Professor

Department : Mechanical Engineering

Qualification : PhD Energy Studies (IIT, Delhi), M.Tech Industrial Engineering (GNEC, Ludhiana),

B.Tech Mechanical (GNEC, Ludhiana),

Research Interests: Alternative Fuels for Combustion Engines, IC engine Emission Control, Engine Combustion Investigations, Biodiesel Development, Fuel Efficient Engines. 